\title{
Information Literacy for Future Teachers
}

\author{
Ivana Batarelo Kokić \\ Faculty of Philosophy, University of Split \\ Sinjska 2, 21000 Split, Croatia \\ E-mail: batarelo@ffst.hr
}

Received: September 18, 2011

Accepted: October14, $2011 \quad$ Published: February 1, 2012

doi:10.5430/wje.v2n1p45

URL: http://dx.doi.org/10.5430/wje.v2n1p45

\begin{abstract}
The main goal of this study is to evaluate primary teacher education programs in Croatia. Prior to evaluation of the primary teacher education programs, expected primary teacher education competencies were defined. The expected teacher competencies were determined according to the goals stated in the Croatian national curriculum. In addition, international guidelines for information literacy development among primary education teachers were used. An extensive literature review on information literacy curriculum in teacher education higher education was conducted as a part of this study. The evaluation of primary teacher education programs is conducted according to the content analysis methodology. Since current primary teacher education programs do not state learning outcomes, future teacher competences are evaluated according to the state course goals. The content analysis indicates that the majority of the current primary teacher education programs include goals that could be linked to information literacy standards. Future teachers are most frequently taught how to evaluate information, but lack instruction on fair use of information. The discussion includes recommendations to raise information literacy among teacher educators and to align course syllabi with the common theoretical frameworks.
\end{abstract}

Keywords: Higher education; Teacher education curriculum, Curriculum research, Information literacy

\section{Introduction}

According to the recent developments information literacy is a skill that has to be acquired in the primary schools. The concept of information literacy was first introduced in 1974, when Paul Zurkowski suggested that 1) information resources are applied in a work situation; 2) techniques and skills are needed for using information tools and primary sources; and 3) information is used in problem solving (Behrens, 1994). Nowadays, the majority of information literacy interpretations are associated with lifelong learning. According to UNESCO (2006) information literacy is a vital element for successful lifelong learning. The concept of lifelong learning has evolved with an increased need for employees to acquire new competences at the workplace (Kendall, 2005). According to the most common definitions, information literacy has a large impact on the development of problem based learning skills, and direct influence on the life accomplishments (Chambers, 2002). Since information literacy should be introduced in the primary schools, teachers become a main link in the information literacy development. Information literacy initiatives in higher education seek to meet the demands of the knowledge based and information society (Petrides \& Nodine, 2003). Chevillott (2007) emphasizes that positive changes outside the universities influence information literacy requirements for all future school teachers. Williams \& Coles (2007) write that teachers' information literacy skills greatly influence use of research evidence in their work and the development of an information culture within schools. It is apparent that primary school teachers should be have information literacy competency in order to function in the nowadays schools and changes in initial teacher education are of a great importance. Hence, in this research study we aim to answer the following questions:

1) What types of the information literacy standards are present in the primary teacher education program syllabi?

2) What types of goals relate to the particular information literacy standards present in the primary teacher education program syllabi?

\section{Theoretical Framework}

\section{1 Higher Education and Teacher Education}

When looking into teacher education it is necessary to place it in the wider context of higher education. Due to 
implementation of the Bologna process, Croatia is passing through an ongoing reform of higher education. The rationale behind the Bologna process is to create the common area of European higher education, by the means of more comparable and compatible academic degree and quality assurance standards throughout Europe (Benelux Bologna Secretariat, 2007). While the Bologna process has a strong emphasis on lifelong learning (The European Association for University Lifelong Learning, 2005), it also requires continuous evaluation of students through their involvement in problem solving activities, critical thinking and active learning, which are some of the information literacy indicators. The implementation of the Bologna process throughout European higher education includes wide number of the bodies and institutions, and involves highly structured strategy planning and implementation efficiency analysis (Kettunen, \& Kantola, 2006). Bologna process reinforced positive changes in regards to inclusion of information literacy in the new definition of ECTS (Chevillotte, 2007). Lončarić \& Pejić Papak (2009) gave an overview of European and Croatian policies in the area of teacher education. They write about demands that are placed in front of teachers by the contemporary curriculum, providing the examples of national guidelines and standards including teacher competences. Literacy development among preservice teachers should be discussed in relation to the teacher competencies listed in the European Qualifications Framework (European Commission: Education and Culture, 2008). According to European Qualifications Framework the competency profile for teacher preparation programs should include language, mathematics, and information-communications competencies. There is limited theoretical alignment of the current educational policy documents and higher education programs documentation in Croatia. While current educational policy documents typically discuss future teacher competencies, actual teacher education program documentation at universities in Croatia remains on the level of course goal definition. While course goals broadly state what the student will be able to do upon completion of the instruction, according to Spady (1977) competency based education approach implies framing of outcome goals in applied life-role terms and making major changes in curricula, instruction and evaluation procedures.

\subsection{Literacy and Information Literacy}

Learning to learn is one of the lifelong learning key competences (European Commission, 2004). Education Council (2006) provides an extensive definition of the learning to learn concept which includes: the ability to pursue and persist in learning, the ability to organize one's own learning, effective management of time and information, awareness of one's learning process and needs, ability to identify available opportunities, the ability to overcome obstacles in order to learn successfully and the ability to gain, process and assimilate new knowledge and skill as well as seeking and making use of guidance.

Similar to the definition of an information literate person given by the American Library Association standards, the development of learning to learn competence is closely related to the level of information literacy skill development. According to the American Library Association (2006), the information literate person is able to: (a) determine the information needed; (b) access needed information; (c) evaluate information; (d) use information; and (e) understand economic, legal, and social issues surrounding the use of information. Educational policy makers need to include the lifelong learning requirements into all aspects of educational provisions (Kendall, 2005). With a goal to educate information literate students, it is necessary to incorporate information literacy across curricula, in different programs and university services. Achieving the goal of educating information literate students requires collaborative efforts among faculty, librarians, and university administrators (American Library Association, 2006). Several researchers write about collaboration between librarians and faculty in order to promote information literacy that is directly linked to critical literacy (Jacobs, 2008; Elmborg 2006). Jacobs (2008) examines information literacy pedagogy and suggests that academic librarians can improve pedagogical praxis by encouraging students to be engaged learners. This postulate is in line with Freire's critical pedagogy where teachers become engaged learners, delve into problem posing, and embody the kind of engagement they want to see in students. Elmborg (2006) uses critical literacy theory to define information literacy and suggests that focus of librarians' work should not be solely information transfer but also development of students' critical consciousness.

The literature review indicates that the traditional notion of information literacy is inadequate to address the learning needs of students in the 21 st century. It is necessary to adjust curricular and teaching approaches in higher education to develop students' information literacy (Johnston \& Webber, 2003; Williams \& Coles, 2007). Current information literacy practices are associated with surface learning approaches, lack of engagement by teachers, lack of educational training for librarians and poor assessment methods (Johnston \& Webber, 2003; Williams \& Coles, 2007). In contrast, Kellner (2000) argues that that multiple literacies are needed in multicultural society. These new literacies should meet the challenge of the new technologies while nurturing print literacy. Bawden (2001) definition of information and digital literacy states that these are general concepts which are based on knowledge, perceptions and attitudes, but still include simple skills-based literacies. While emphasizing that information literacy is one of the initial elements of the 
information culture, Gilyarevskii (2007) writes that information literate students should be able to find, use, and protect information.

\subsection{Information Literacy Curriculum Research}

Several research studies determined an overall positive impact of implementation of information literacy curriculum in the higher education arena (Branch, 2003; Brown \& Krumholz, 2002; Rader, 1995). Rader (1995) writes that efforts of academic librarians in integration of information literacy into the undergraduate curriculum were successful due to implementation of technological developments and educational reforms. More specifically, Branch (2003) examined impact of an information literacy course on students' information-seeking behaviors. The study participants indicated that knowledge and skills they gained were transferrable to the work and home environment. The findings of the Brown \& Krumholz (2002) study are ambivalent. The authors determined that direct instruction in the use of bibliographic finding tools increased some of the information literacy related skills. Although the participants were required to critique and discuss information, these skills were not improved during the study.

Research studies on information literacy curriculum for preservice teachers were of particular interest for this paper. Findings indicated an overall positive impact of direct instruction on information literacy (Chambers, 2002; Novosel \& Batarelo, 2008) and benefits of collaboration among teacher educators and librarians (Duke \& Ward, 2009; Floyd, Colvin, \& Bodur, 2008). Novosel and Batarelo (2008) determined levels of information literacy among pedagogy majors. A quantitative methodology was used to determine differences in information literacy, frequency and extent of library catalogue and database use between students. Students who had courses that dealt with database search and scientific writing skills significantly higher scores on the information literacy test. Chambers (2002) revealed substantial benefits for teacher education students when using a problem based learning approach for information literacy and independent learning skills instruction. Floyd, Colvin and Bodur (2008) indicates statistically significant changes in information literacy levels among preservice teachers when they were involved with librarians in the information literacy teaching process. Duke and Ward (2009) conducted a metasynthesis of empirical and nonempirical literature focusing on to the preparation of information literate teachers. The results indicate positive impact of collaboration between teacher educators and librarians in order to prepare teachers to teach information literacy skills.

\subsection{Information Literacy Curriculum Formats}

Typically, courses that facilitate information literacy development are student-centered and rely on inquiry and problem solving activities (American Library Association, 2006). This type of courses could be taught both by faculty and academic librarians. Findings from several research studies indicate that the increase in preservice teachers information literacy is a result of combination of library instruction and guidelines given by faculty (Cooney \& Hiris, 2003; Floyd, Colvin, \& Bodur, 2008; Owusu-Ansah, 2004).

In a research of information literacy curriculum formats, of a great importance are studies dealing with the course information literacy content. Warner (2008) analysed teacher education syllabi in order to identify the information literacy skills that were taught in the courses as reflected in the course description and description of the assignments. However, Warner found that, even though information literacy objectives were identified in the syllabi, there is no assurance that all aspects of the objective were taught. Novosel and Batarelo (2008) analyzed undergraduate study program to identify teaching approaches for the pedagogy majors. There is a one core course which directly focuses on the development of the digital and information literacy skills. Additionally, several other courses taught during the first, second, and third years of study also include problem-solving activities that facilitate information literacy development.

Several researchers propose new information literacy frameworks for higher education (Brown \& Krumholz, 2002; Markless, 2009. Based on research results, Brown and Krumholz (2002) propose an information literacy curriculum model according to which library instruction should a) be paired with critical analysis of the research literature, b) include instruction in time management and documentation of sources consulted, c) explain details about the accessibility of external resources and the details on key word and subject searching, d) be scheduled in shorter and more frequent sessions for, both individual and group learning sessions, and e) make materials available on the Web. Markless (2009) offers a new information literacy framework based on the idea to support student choice in learning rather than teaching information literacy. The framework offered tasks that combine academic work content and process together, activities that enable students to recognize and reflect on current information strategies and skills. Finally, the activities should be based on the principles of constructivism, requiring a high level of intellectual engagement from the students.

\subsection{Literature Review Summary}

The graphic in Figure 1 is derived from the literature review that focused on higher education and teacher education, 
literacy and information literacy, information literacy curriculum research and information literacy curriculum formats. Issue of the future teacher information literacy in educational policy documentation is presented through variety of documents on information literacy standards, lifelong learning policy, Bologna process and European Qualifications Framework. These documents promote learning to learn competence and directly influence teacher education programs.

<Figure 1 about here>

The findings of the analyzed research studies in regards to information literacy development may be grouped around three main conclusions: (1) there is a positive impact of collaboration between faculty and librarians, (2) positive impact of technological developments on the information literacy competencies of future teachers, and (3) positive impact of direct instruction on information literacy across curriculum. Finally, the reviewed literature indicates that proposed curricular formats for information literacy teaching at higher education institutions proceed from the relevant research findings.

\section{Primary Teacher Education Programs Analysis}

\section{1 Methodology}

The technique of content analysis was used to gather the frequency of information literacy content incidents. A similar analysis was conducted by Mbabua (2007) who collected primary teacher education syllabi from the Internet and designed an instrument focusing on the analysis of teacher education programs and educational levels. The following procedure from Mbabua (2007) was adopted and applied in the current study:

1. Available primary teacher education programs were selected for analysis. Those whose syllabi were publicly posted on the World Wide Web were identified and harvested.

2. Two coders participated in the coding process. Both coders were trained on the common text in order to establish intercoder reliability. The practice session was conducted using syllabuses separate from the syllabuses that were part of the primary teacher education programs selected for analyses. Through the training session, coders were familiarizing with the coding procedure and developing a consensus on the definitions of the categories. Content analysis software was not used for this study purpose.

3. Contingency tables were constructed for recording the number of information literacy related goals present in the syllabi. The analyzed teacher education programs syllabi include course goals, while specific instructional objectives are not included. The table is constructed according to the ALA information literacy standards (2000) and Warner's syllabi analysis of information literacy skills (2008).

4. Collected data were analyzed by researcher.

\subsection{Analysis Results}

<Table 1 about here>

Five information literacy standards (ALA, 2000) with the abbreviated titles used in this research are listed in table 1. In the attempt to answer the first research question on types of the information literacy standards which are present in the primary teacher education program syllabi, the analyzed data is quantified and presented in table 2 . One count indicates the presence of at least one information literacy related goal per course. The data in the rows represent the count of goals related to information literacy in either core or elective courses for the programs at four universities. A visual inspection of the table shows that the four teacher education programs differed slightly according to the syllabus structure, but all four programs clearly stated course goals related to information literacy and types of information literacy standards which are present in the primary teacher education program syllabi. The most common information literacy standard is related to evaluation of information, this standard is followed by effective use of information standard, effective access to information standard, ability to determine information need standard and fair use standard.

$<$ Table 2 about here>

Further descriptive analysis was needed to answer the second research question on types of goals that relate to the particular information literacy standards present in the primary teacher education program syllabi. Hence a separate description of each analyzed study program is presented in the below sections.

The overview of the primary teacher education study program at University in Pula indicates that there is a larger number information literacy relevant goals among core courses. The most frequently occurring information literacy goals are those that could be linked to the information evaluation standard. The reviewed courses, list the goals related to students' critical reflection on certain educational problems, critical thinking that includes summarizing and evaluation of ideas, and strategic approach to reading. The second most frequently occurring information literacy 
standard present among course goals is access to needed information. In different courses, students are taught how to select efficient and effective approaches for accessing the information from media, literature and how to select school documents. In research methods course, students are taught to identify appropriate investigative methods in order to reach research results. Effective information use related goals are: use of information in educational environment, use of information in research, communicating product or performance to other by use gathered scientific information in written or oral form. Fair use is recognizable through appropriate conduct with statutory and school documents and it is listed as a goal in for the teaching practice. The only course in which the stated goal is to enable students to determine nature and extent of information needed is the educational research methodology course. The research process requires the ability to recognize specific needs for information, to articulate information needs, and to consider cost and benefits of acquiring the needed information.

The most frequently occurring information literacy standards among teacher education program goals at the University of Split are linked to evaluation of information. These goals are present both among core and elective courses and are related to: logical analysis of the text, critical thinking, research capabilities that include evaluation of information, ability to use information, evaluation of ideas and experiences. One of the courses states that media literacy is a course goal, and media literacy included evaluation of information. Effective information use standard related goals are: use of information when dealing with different themes and in different areas, and in concrete educational environment, use of scientific results in professional work which includes ability to communicate information to others, team work and problem solving. Media literacy development among other things includes ability to communicate product or performance effectively to others. Access to needed information related goals are: identifies appropriate investigative methods for scientific work, selecting efficient approach for accessing information from different sources. Fair information use development of media literacy that includes understanding of ethical, legal and socio-economic issues surrounding information and produced materials, ability to use information according to law and regulations and institutional policies. Standard related to determining nature and extent of information needed is addressed with the following goals: enabling students to find interesting and relevant motives for artistic expression and creation, media literacy development which includes identifying a variety of types and formats of potential sources for information, research skills and critical thinking skills that require ability to define and reevaluate the nature and extent of the information need.

Similarly to the teacher education programs at other universities, the most frequently occurring information literacy standard at the Josip Juraj Strossmayer University, Osijek is evaluation of information. This standard may be achieved with the following goals present both among core and elective courses: critical thinking, literature use and analysis of the written text that includes ability to synthesize and summarize main ideas, learning research methods that require ability to articulate and apply evaluation criteria, Internet search and media use that require from student to apply evaluation criteria. Effective information use standard may be achieved through literature, media and internet use that require students to apply new and prior information in the creation of the course tasks. Access to needed information standard is achieved in a research methodology and teaching methods courses. While research methodology requires ability to select the most appropriate investigative methods, teaching methods courses requires a certain level of independence from students and ability to manage information and sources. Standard related to determining nature and extent of information needed is achieved through the following goals: ability to define and articulate research information, ability to identity different formats and sources of information that could be used in curriculum development, preparation of teaching materials and actual teaching. The least frequently occurring information literacy standard this teacher education program is a fair information use. The goals which relate to this standard are mentioned in the research methodology course, where research practices should be aligned with the laws and regulations. A similar result can be seen with the teaching practice and teacher ethics courses that require future teachers to be able to follow institutional policies related to access and use of information.

The teacher education program at the University of Rijeka most commonly includes goals that could be related to the information evaluation standard. These goals are predominantly present in description of core courses and according to them, students should be able to compare and evaluate various topics, analyze information from various sources, apply skills of critical thinking and use research skills. Critical thinking and research skills include the ability to evaluate information. A relatively large number of courses state goals that could be related to effective information use standard. These goals require students to be able to organize and use information in appropriate context and ability to manage and present information. Access to needed information standard related goals demand from students to be able to: find needed information, manage information and obtain information from various sources. Standard related to determining nature and extent of information needed is met by goals that state that students should be able to work independently, which involves ability to define and identify needed information and by the goal that requires from 
students to apply logical thinking. The least frequently occurring information literacy standard is related to fair information use. This standard is met by the goals stating that students should be able to apply research skills, which implies understanding of ethical issues surrounding information and appropriate use of topics.

\subsection{Study Limitations}

The primary teacher education programs that were used for analysis are programs licensed by the state Ministry of Science, Education and Sport. Limitations of the study are related to the fact that analyzed syllabuses were included in the official programs published three to five years ago and it is likely that teacher educators are implementing considerable changes to their syllabuses each semester. Also, the extended versions of the syllabuses which are not readily available online may include learning outcomes that could give more insight into how the information literacy curriculum is implemented. Although teacher educators are likely to use extended versions of the syllabi, these syllabi are not validated by the relevant Ministry and for that reason are not used in the study.

Currently there are eight teacher education programs in Croatia and four of them were analyzed as a part of this study. Although the study findings indicate similarities in regards to the presence of information literacy related goals among analyzed teacher education programs, it is necessary to be cautious when generalizing these study findings to other university programs.

\section{Discussion}

The majority of the research studies critiqued in this review show that there is a positive impact of the information literacy related content on the various aspects of students' information literacy. Nevertheless, when discussing research findings based on the analysis of the teacher education programs, further research is needed to understand the complexities of teaching practices considering actual implementation of the analyzed syllabuses. More in-depth analysis would reveal the level of actual implementation of information literacy in preservice teacher education programs. This analysis should be based on the extended course syllabi that might offer insight on the teaching-learning procedures and actual learning outcomes. Furthermore, researchers might follow up with direct observations of graduates to notice how information literacy competencies are being implemented with pupils.

The evaluated primary teacher education programs are entering an official review process in the academic year 2011/2012, hence this study could be of a great relevance both to the field of study and teacher education practitioners. This study results may have an impact on the changes in the preservice teacher education curriculum. The analysis revealed that primary teacher education programs are not following theoretical frameworks described in the literature review. In addition to a lack of theoretical frameworks, some of the primary teacher education programs at universities in Croatia do not require teacher educators to state course goals in their syllabi. Hence, it was not possible to analyze these programs for purposes of this study. The analyzed primary teacher education programs in Croatia differ according to the presence of the information literacy relevant goals. Nevertheless, it is apparent that the programs are rather similar according to information literacy standards that they are focusing on. The findings regarding presence or absence of certain information literacy standards in the teacher education programs may be taken into consideration in the program revisions. The most frequently occurring information literacy standard is evaluation of information. The second most frequently occurring standard is the effective information use standard, after which follows access to needed information standard. Not many programs included goals related to determining the nature and extent of information needed and fair information use principles. The analysis of course descriptions revealed that the least focus was given to fair use. Future teachers in their work will frequently deal with fair use issues such as imitation and plagiarism, Xeroxing multiple copies of copyrighted materials, and so on. Knowing the high importance and actuality of the fair use issue in educational environments, this finding should be should also be reviewed from the wider sociological scope.

Although the analysis revealed that number of course goals related to information literacy, it is apparent that teacher educators do not necessarily think about information literacy when writing these goals and this finding may have impact on the field of study. The majority of the goals that were recognized as related to information literacy are linked to the development of critical thinking skills, problem solving and decision making, which are popular terms in professional literature. The question remains, how do teacher educators teach these skills in their courses. More direct guidance for teacher educators should be provided, in order for them to recognize the importance of information literacy and find the way to implement elements of information literacy in their courses. 


\section{References}

American Library Association (2000). Information Literacy Competency Standards for Higher Education. Chicago, IL: American Library Association. [Online] Available: http://www.ala.org/ala/mgrps/divs/acrl/standards/standards.pdf

Bawden, D. (2001). Information and digital literacies: a review of concepts. Journal of Documentation, 57(2): 218-259, http://dx.doi.org/10.1108/EUM0000000007083

Behrens, S. J. (1994). A conceptual analysis and historical overview of information literacy. College and Research Libraries, 55(4): 309-322.

Benelux Bologna Secretariat. (2007). Bologna Process 2007-2009. [Online] Available: http://www.ond.vlaanderen.be/hogeronderwijs/bologna/

Branch, J. L. (2003). Nontraditional undergraduates at home, work, and school: an examination of information-seeking behaviors and the impact of information literacy instruction. Research Strategies, 19(1), 3-15, http://dx.doi.org/10.1016\%2Fj.resstr.2003.09.002

Brown, C. \& Krumholz, L. R. (2002). Integrating Information Literacy into the Science Curriculum. College \& Research Libraries, 63(2): 111-123.

Chambers, D (2002). Using problem based learning to hone information literacy and independent learning skills. Lifelong Learning Conference. [Online] Available: http://lifelonglearning.cqu.edu.au/2002/papers/chambers.pdf

Chevillotte, S. (2007). French Speaking Countries: Belgium, France, Quebec, Switzerland Information Literacy State-of-the Art Report. In Lau, J. (Ed.) Information literacy: an international state of the art report. InfoLit Global. [Online] Available: http://www.ifla.org/files/information-literacy/UNESCO_IL_state_of_the_art_fre_2010.pdf

Cooney, M. \& Hiris, L. (2003). Integrating information literacy and its assessment into a graduate business course: A collaborative framework. Research Strategies, 19(3/4): 213-232, http://dx.doi.org/10.1016\%2Fj.resstr.2004.11.002

Duke, T. S. \& Ward, J. D. (2009). Preparing information literate teachers: A metasynthesis. Library \& Information Science Research, 31(4): 247-256, http://dx.doi.org/10.1016\%2Fj.lisr.2009.04.003

Education Council (2006). Recommendation of the European Parliament and the Council of 18 December 2006 on key competencies for lifelong learning. Brussels: Official Journal of the European Union, 30.12.2006

Elmborg, J. (2006), Critical Information Literacy: Implications for Instructional Practice. The Journal of Academic Librarianship, 32(2): 192-199, http://dx.doi.org/10.1016\%2Fj.acalib.2005.12.004

European Commission. (2004). Key competences for lifelong learning a European reference framework. [Online] Available: http://ec.europa.eu/education/policies/2010

European Commission: Education and Culture (2008). The European Qualifications Framework for Lifelong Learning $(E Q F)$. [Online] Available: http://ec.europa.eu/dgs/education_culture/publ/pdf/eqf/broch_en.pdf

Floyd, D. M., Colvin, G., \& Bodur; Y. (2008). A faculty-librarian collaboration for developing information literacy skills among preservice teachers. Teaching and Teacher Education, 24(2): 368-376, doi:10.1016/j.tate.2006.11.018, http://dx.doi.org/10.1016\%2Fj.tate.2006.11.018

Gilyarevskii, R. S. (2007), Information Culture in Higher Education. Scientific and Technical Information Processing, 34(1): 40-43, http://dx.doi.org/10.3103\%2FS0147688207010066

Jacobs, H. L. M. (2008). Information Literacy and Reflective Pedagogical Praxis. The Journal of Academic Librarianship, 34(3): 256-262, http://dx.doi.org/10.1016\%2Fj.acalib.2008.03.009

Johnston, B. \& Webber, S. (2003). Information Literacy in Higher Education: a review and case study. Studies in Higher Education, 28(3): 335-352, http://dx.doi.org/10.1080\%2F03075070309295

Josip Juraj Strossmayer University (2005). Integrated undergraduate and graduate five-year university class teacher studies. Osijek: Josip Juraj Strossmayer University, The Faculty of Teacher Education. [Online] Available: http://www.ufos.hr/DATA/studijski_programi/Class_teacher_Osijek.pdf

Juraj Dobrila University of Pula (2008). Studijski program integriranog preddiplomskog i diplomskog sveučilišnog učiteljskog studija s izmjenama i dopunama. Pula: Juraj Dobrila University of Pula, Department of Preschool and Primary Education. [Online] Available:

http://www.unipu.hr/uploads/media/Microsoft_Word_-_INTEGRIRANI_SVEUCILISNI_UCITELJSKI_STUDIJ__s_izmjenama_i_dopunama_02.pdf 
Kellner, D. (2000). New Technologies/New Literacies: reconstructing education for the new millennium. Teaching Education, 11(3): 245-265, http://dx.doi.org/10.1080/713698975

Kendall, M. (2005). Lifelong Learning Really Matters for Elementary Education in the 21st Century. Education and Information Technologies, 10(3): 1573-7608, http://dx.doi.org/10.1007\%2Fs10639-005-3011-x

Kettunen, J. \& Kantola, M. (2006). The implementation of the Bologna Process. Tertiary Education Management, 12(3): 257-267, http://dx.doi.org/10.1080\%2F13583883.2006.9967172

Lončarić, D., \& Pejić Papak, P. (2009). Profiliranje učiteljskih kompetencija. Odgojne znanosti, 11(2): 479 - 497.

Markless, S. (2009). A New Conception of Information Literacy for the Digital Learning Environment in Higher Education. Nordic Journal of Information Literacy in Higher Education, 1(1), 25-40.

Mbabua, L. G. (2007). Content analysis of information literacy courses in master's degree programs of library and information studies. Unpublished doctoral dissertation. Athens, OH: Ohio University.

Novosel, V. \& Batarelo, I. (2008). Information Literacy among Pedagogy Majors. Poster Abstracts of the ITI 2008: 30th International Conference on Information Technology Interfaces / Lužar-Stiffler, Vesna ; Hljuz Dobrić, Vesna ; Bekić, Zoran (Eds.). - Zagreb: University of Zagreb, University Computing centre SRCE , 23-24.

Owusu-Ansah, E. K. (2004). Information Literacy and Higher Education: Placing the Academic Library in the Center of a Comprehensive Solution. The Journal of Academic Librarianship, 30(1): 3-16, http://dx.doi.org/10.1016\%2Fj.jal.2003.11.002

Petrides LA, \& Nodine TR. (2003). Knowledge management in education: Defining the landscape. The Institute for the Study of Knowledge Management. [Online] Available: http://www.iskme.org/kmeducation.pdf

Rader, H. B. (1995). Information Literacy and the Undergraduate Curriculum. Library Trends, 44(2): 270-278.

The European Association for University Lifelong Learning (2005). University lifelong learning in the Bologna process: From Bergen to London and beyond. [Online] Available: http://www.eucen.org/

UNESCO (2006). Information Literacy key for lifelong learning. Information Literacy Summit. [Online] Available: http://portal.unesco.org/ci/en/

Spady, W. G. (1977). Competency based education: A bandwagon in search of a definition. Educational Researcher, 6(1), 9-14. http://dx.doi.org/10.2307/1175451

Sveučilište u Rijeci (2008). Studijski program - Integrirani preddiplomski i diplomski sveučilišni učiteljski studij. Rijeka: Sveučilište u Rijeci, Učiteljski Fakultet u Rijeci. [Online] Available: http://www.ufri.uniri.hr/data/sveucilisni\%20uciteljski\%20studij.pdf

Sveučilište u Splitu (2005). Nastavni plan i program - Integrirani sveučilišni studij za prvostupnika i magistra primarnog obrazovanja. Split: Sveučilište u Splitu, Filozofski fakultet. [Online] Available: http://www.ffst.hr/odsjeci/uciteljski/program.pdf

Warner, D. A. (2008). A Disciplinary Blueprint for the Assessment of Information Literacy. Westport, CT: Libraries Unlimited.

Williams D, Coles L. (2007). Teachers' approaches to finding and using research evidence: an information literacy perspective. Educational Research, 49(2): 185 - 206, http://dx.doi.org/10.1080\%2F00131880701369719 
Table 1. Information literacy standards (ALA, 2000)

\begin{tabular}{|c|l|l|}
\hline Standard & \multicolumn{1}{|c|}{ Full description } & \multicolumn{1}{|c|}{ Abbreviated title } \\
\hline Standard 1 & $\begin{array}{l}\text { The information literate student determines the nature and extent of } \\
\text { the information needed. }\end{array}$ & $\begin{array}{l}\text { Determine extent of } \\
\text { needed information }\end{array}$ \\
\hline Standard 2 & $\begin{array}{l}\text { The information literate student accesses needed information } \\
\text { effectively and efficiently. }\end{array}$ & $\begin{array}{l}\text { Access needed } \\
\text { information }\end{array}$ \\
\hline Standard 3 & $\begin{array}{l}\text { The information literate student evaluates information and its } \\
\text { sources critically and incorporates selected information into his or } \\
\text { her knowledge base and value system. }\end{array}$ & Evaluate information \\
\hline Standard 4 & $\begin{array}{l}\text { The information literate student, individually or as a member of a } \\
\text { group, uses information effectively to accomplish a specific } \\
\text { purpose. }\end{array}$ & $\begin{array}{l}\text { Effective information } \\
\text { use }\end{array}$ \\
\hline Standard 5 & $\begin{array}{l}\text { The information literate student understands many of the } \\
\text { economic, legal, and social issues surrounding the use of } \\
\text { information and accesses and uses information ethically and } \\
\text { legally. }\end{array}$ & $\begin{array}{l}\text { Fair use of } \\
\text { information }\end{array}$ \\
\hline
\end{tabular}

Table 2. Information literacy related goals contingency list

\begin{tabular}{|l|l|l|l|l|c|c|}
\hline \multirow{2}{*}{ University } & \multirow{2}{*}{$\begin{array}{c}\text { Course } \\
\text { Type }\end{array}$} & $\begin{array}{l}\text { Information Literacy Standards } \\
\text { of needed } \\
\text { information }\end{array}$ & $\begin{array}{l}\text { Access needed } \\
\text { information }\end{array}$ & $\begin{array}{l}\text { Evaluate } \\
\text { information }\end{array}$ & $\begin{array}{l}\text { Effective } \\
\text { information } \\
\text { use }\end{array}$ & $\begin{array}{l}\text { Fair use of } \\
\text { information }\end{array}$ \\
\hline \multirow{2}{*}{ Osijek } & Core & 3 & 5 & 7 & 6 & 2 \\
\cline { 2 - 8 } & Elective & 3 & 3 & 5 & 4 & 2 \\
\hline \multirow{2}{*}{ Pula } & Core & 1 & 5 & 10 & 6 & 2 \\
\cline { 2 - 8 } & Elective & 0 & 3 & 4 & 3 & 0 \\
\hline \multirow{2}{*}{ Rijeka } & Core & 6 & 9 & 11 & 8 & 2 \\
\cline { 2 - 8 } & Elective & 1 & 2 & 5 & 5 & 3 \\
\hline \multirow{2}{*}{ Split } & Core & 1 & 3 & 8 & 9 & 1 \\
\cline { 2 - 8 } & Elective & 4 & 35 & 60 & 46 & 14 \\
\hline
\end{tabular}




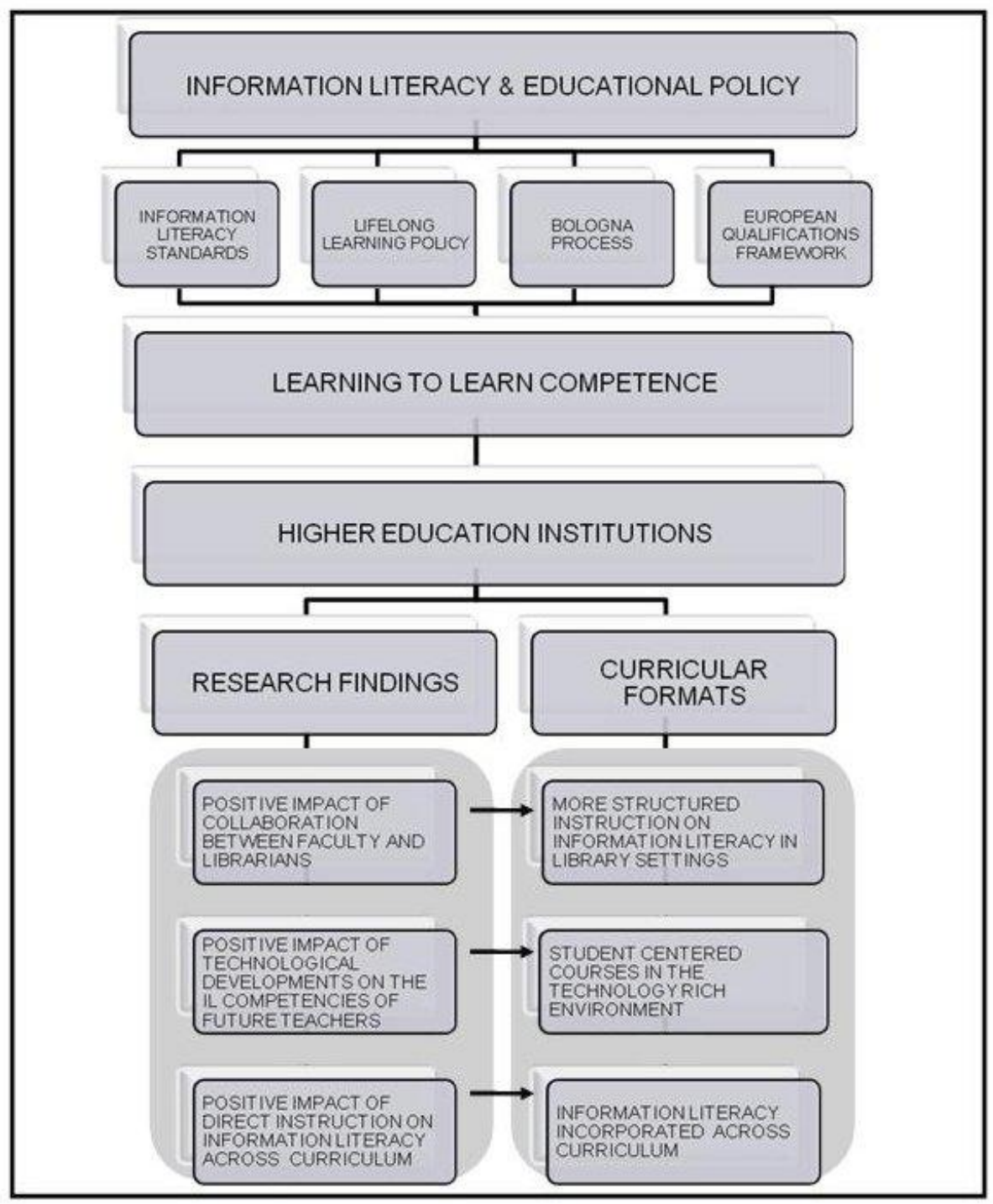

Figure 1. Information literacy related policies and its influence on teacher education curriculum 